\title{
Decision Determination with Hedging Financial Derivative Instruments in the Manufacturing Sector Company
}

\author{
Yuhasril, Yuhasril (yuhasril@mercubuana.ac.id) \\ Tri Wahyono (triwahyono@mercubuana.ac.id) \\ Sumiyarsih, Sumiyarsih. Trisakti School of Management.
}

\begin{abstract}
Hedging is an alternative of company that aims to protect the assets of company from losses caused by the risk. This study purposed to analyze the influence of independent variables which include firm size, growth opportunity, liquidity, and leverage on determined hedging decision using derivative instruments at manufacturer companies listed on the Indonesia Stock Exchange in 2015-2018. Sample selection method used in this research is purposive sampling method with criteria manufacturer companies basic industry and chemicals, and miscellaneous industry sector and the publication of annual financial report routine since 2015-2018. This method result samples 40 companies for research. This study using logistic regression analysis, to find sets of independent variables that affect the probability the use of derivative instruments as hedging activities. The results showed that variable firm size has significant effect on hedging decision. Variable growth opportunity, liquidity and leverage has not significant effect on hedging decision.
\end{abstract}

Keywords: Hedging, Derivative Instruments, Firm Size, Growth Opportunity, Liquidity, Leverage

DOI: $10.7176 /$ RJFA/11-18-20

Publication date:September $30^{\text {th }} 2020$

\section{PRELIMINARY}

International trade as one part of economic activity shows a fairly rapid development in the period of increased business attention on international business activities. International trade can be seen from the activity of trading goods and services as well as foreign investment which results in capital inflows and capital outflows. International trade is related to payments between countries with different currencies, which causes fluctuating foreign exchange rates. Until now, the US dollar is one of the most powerful major currencies, because it is used in almost all countries in the world. Since the economic crisis in 2009, the United States has continued to improve the economy by gradually increasing interest rates through the US central bank, the Federal Reserve or the Fed. In 2018, the Fed has raised the Federal Funds Rate (FFR) up to three times by 100 basis points (bps), continuing the response of the previous increase of $75 \mathrm{bps}$ in 2017. In addition to raising interest rates, the United States also adopted normalization of monetary and fiscal policies, which made investors begin to reallocate their assets, even bringing back the US dollar due to greater yields. The increase in FFR which was aligned with the decline in Fed ownership in the UST, had an impact on increasing external pressures and capital outflows from investors. This development pushed the US dollar to strengthen globally as reflected in the US dollar index which increased from 92.1 in 2017 to 96.2 in 2018 .

Other factors that influence fluctuations in foreign exchange rates are caused by the increasing tension in world trade relations between the United States and other countries, which gives negative sentiment to emerging market countries, such as Indonesia. Tension in world trade relations has escalated since early 2018, when the United States imposed import tariffs on solar panels and washing machines. Followed in June 2018, the United States imposed export tariffs on steel and aluminum from Europe, Canada, and Mexico, which encouraged retaliation of their heads. In the same month, the United States also announced plans to impose import tariffs on China which were also reciprocated by China. And at the end of 2018, the US has imposed import tariffs on imported products from China with a total value of 250 billion US dollars. Conversely, China also imposes import tariffs on imported products from the US worth 110 billion US dollars.

Indonesia is one of the countries that has a large dependence on the US dollar exchange rate. The global economic situation is not favorable for the economy, including the state budget which has macroeconomic assumptions referring to the benchmark exchange rate of the rupiah against the US dollar. The sector most directly affected by the weakening of the exchange rate is the industrial sector, especially manufacturing. The manufacturing industry is one of the strategic sectors because it plays a role in national development and contributes to economic growth (Ministry of Industry, 2017). The application of the floating exchange rate system in Indonesia also increases the risk of fluctuations in foreign exchange rates (Guniarti, 2014). 
The movement of foreign exchange rates will be influenced by uncertainty in the world economy, which among others is triggered by policy changes in developed countries, rising interest rates in developed countries, trade wars, and economic problems in developing countries. As quoted by Tempo.Co, Jakarta, Minister of Finance Sri Mulyani Indrawati said that the 2020 State Revenue and Expenditure Budget was designed to anticipate uncertainties, whether coming from the global, in the event of economic downturn, or domestically, in the event of a natural disaster. Anticipating the negative effects of fluctuations in foreign exchange rates, and protecting the interests of shareholders, the company carries out a hedging policy with derivative instruments (Feriyanto, 2015, p.10).

Hedging is one of the strategies or actions taken to minimize risk but still be able to benefit in business transactions (Wiyono and Kusuma, 2017, p.405). Executive Director of the International Department of BI Doddy Zulverdi said that hedging is an insurance for companies to anticipate the calamity that might occur, in this case the decline in the exchange rate of the rupiah against the US dollar (Indonesian CNN). Hedging can also enable companies to predict future cash expenditures and receipts more accurately, so as to enhance the quality of cash budgeting decisions.

Market risk until 2018, remains under control because it is supported by an increase in hedging ratios and liquidity ratios by corporate companies. This development is reflected in the increase in compliance with the application of the precautionary principle (KPPK). The ratio of compliance with hedges for $0-3$ months increased to $89.3 \%$ in the second quarter of 2018 and $90.2 \%$ in the second quarter of 2018. Meanwhile, the ratio of compliance with hedging ratios for 3-6 months and the ratio of compliance with the ratio Corporate liquidity also reached the highest level in the third quarter of 2018 , which was $95.2 \%$ and $88.3 \%$, respectively. In line with KPPK compliance, transaction volumes in the forex derivatives market have increased in almost all types of derivative instruments. The increase in derivative volumes mainly occurred in June 2018 which reached $3.04 \%$ (ptp), with non-bank corporations as the main hedging actors. The increase in transaction volume in the derivatives market, particularly forward transactions in 2018, is supported by additional variations in hedging instruments in the forex derivatives market, namely forward Non Domestic Deliverable Forward (DNDF) types.

Firm Size is the size or size of a company that can be seen from how big the value of equity, the value of sales and the total value of assets. Large companies, of course, will have extensive operational activities and are more risky because there are many trade transactions that occur, especially international trade. In a study conducted by Ahmad, Mardiyati, Nashrin (2015) states that firm size positively and significantly influences hedging decisions with foreign currency instruments. Whereas based on research by Krisdian, Badjra (2017) states that company size has a negative effect on hedging decisions. Firm Growth Opportunities is a growth opportunity for a company in the future. The opportunity for high company growth will show a higher market value among other companies. As a result of high company growth and high market value, it is not uncommon for investors to be willing to invest their funds in companies that have this capability, because it is considered to be a good investment tool. Research by Utami, Sriyanto, Purbasari (2018) states that growth opportunity has a positive effect on hedging decisions. This opinion is in line with research by Wijaya, Astuti, Nugraha (2018), stating that growth opportunity has a significant effect on hedging decision making. The Liquidity Ratio shows the company's ability to meet all its short-term liabilities with its current assets. The Liquidity Ratio gives an indication that the company is able to fulfill its current liabilities without problems. The results of a study conducted by Widyagoca, Lestari (2016) stated that the Current Ratio had a positive but not significant effect. Another study by Sofia, Hedismarlina (2019) states that Current Ratio influences decision making. Leverage Ratios show how much a company uses debt to fund its activities. A high leverage ratio shows that corporate funding is dominated by debt. If a company's debt is denominated in a foreign currency, the company may be exposed to foreign exchange rate risk. Research conducted by Megawati, Wiagustini, Artini (2016) states that leverage has a positive but not significant relationship to hedging decisions. Meanwhile, according to Mata, Pangeran (2016) states that Debt on Equity Ratio does not affect the exposure of the US dollar exchange rate so there is no need to take hedging measures

\section{RESEARCH PURPOSES.}

The objectives to be achieved in this study are: To determine the effect of firm size, growth opportunity, liquidity, and leverage on hedging decision making in manufacturing companies on the Indonesia Stock Exchange. This research is expected to provide the following benefits: to become information and to be one of the inputs in making hedging decisions with foreign exchange derivatives, to be information in considering the benefits and costs arising from hedging activities, reinforcing the theory that hedging is one of the actions to mitigate against exchange rate risk, and becomes additional information and as a reference for research on hedging activities. 


\section{LITERATURE REVIEW}

\section{Risk of Foreign Exchange Fluctuations}

Companies conducting international transactions will have assets and expenses denominated in several foreign currencies. The risk that may occur from this is the risk of fluctuations in foreign exchange rates. Risks arise because the exchange rate of one unit of a country's currency with another country is always changing, and these changes can occur due to differences in conditions in each country, such as differences in growth and inflation rates, differences in interest rates, and so forth. If when a company has a burden on a foreign currency and the foreign currency strengthens against the company's operating currency, then the company cannot avoid increasing the burden caused by changes in the exchange rate.

Transaction Exposures, measure changes in transaction value because there are differences between foreign exchange rates at the time the transaction is agreed upon and when the transaction is completed / fulfilled (Gatot Nazir Ahmad, Umi Mardiyati, and Ahmad Shofi Nashrin, 2015). Companies experience uncertainty because when they have to pay their debts in the future, the exchange rate can change. Implement transaction exposures, i.e. conduct policies in the form of income and expense treatment in foreign currencies in future books and then analyze their effects on net income for potential changes in the foreign exchange rate.

Operating Exposure or also called economic exposure, competitive exposure as well as strategic exposure, measures how much the change in the company's present value due to changes in operating cash flows in the future due to unexpected exchange rate fluctuations. Operational cash flow arises from debts and receivables between companies and between the same units in the company, as well as rent payments from the use of facilities and equipment, royalty fees and licenses to use technology and property rights and costs arising from various management services (Eitman, $2007: 302$ ).

Accounting Exposure or also called translation exposure, is related to the effect of exchange rate movements when a company converts assets and expenses into the domestic currency which results in the difference when converted into the domestic currency. Conversion of financial statements is possible to cause loss or profit. This usually occurs when a company converts the consolidated financial statements of all its overseas subsidiaries into the domestic currency of the central company.

\section{Derivative Instruments of Hedging}

Hedging or hedging is a term that is very popular in futures trading, where hedging is one of the economic functions of futures trading, i.e. transfer of risk. Hedging is a strategy to reduce the risk of loss caused by price fluctuations (Brigham and Houston, 2014.h.359). The benefits of hedging, namely protecting the company's assets from potential foreign exchange losses, as well as reducing variations in future cash flows. The company obtains certainty through hedging.

Hedging techniques are generally used to overcome transaction exposure, including:

1. Mengelola Foreign Exchange Risk.

2. Forward Hedge.

3) Hedge Futures.

4) Money Market Hedge.

5) Currency Option Hedge.

\section{HYPOTHESIS}

Effect of firm size on hedging decisions.

Company size is the size or size of a company that can be seen from how big the value of equity, the value of sales and the total value of assets. Large companies, of course, will have extensive operational activities and are more risky because there are many trade transactions that occur, especially international trade. When companies of large size operate in various countries, these companies will use different currencies. To face the risk of fluctuations in currency exchange rates, companies will tend to apply more hedging policies. In a study conducted by Ahmad, Mardiyati, Nashrin (2015) states that firm size positively and significantly influences hedging decisions with foreign currency instruments. Whereas based on research by Krisdian, Badjra (2017) states that company size has a negative effect on hedging decisions.

H1: Firm Size has an influence on hedging decisions.

The effect of growth opportunities on hedging decisions.

The opportunity for high company growth will show a higher market value among other companies. As a result of high company growth and high market value, investors are willing to invest their funds in companies that have this capability. Funds that can be obtained quickly are by way of debt. But by going into debt, the company will 
increase the risk of default. So, the greater the opportunity for a company to grow, making the company make the decision to hedge. Research by Utami, Sriyanto, Purbasari (2018) states that growth opportunity has a positive effect on hedging decisions. This opinion is in line with research by Wijaya, Astuti, Nugraha (2018), stating that growth opportunity has a significant effect on hedging decision making.

$\mathrm{H} 2$ : Growth Opportunity has an influence on hedging decisions.

Effect of liquidity on hedging decisions.

The liquidity ratio shows the company's ability to meet all its short-term liabilities with its current assets. If the company's current liabilities are denominated in foreign currencies, the company has fluctuations in exchange rates. The more liquid a company is, the more able the company is to fulfill its current liabilities. With an adequate supply of funds, the company does not conduct hedging activities. Research conducted by Megawati, Wiagustini, Artini (2016) states that leverage has a positive but not significant relationship to hedging decisions. Meanwhile, according to Mata, Pangeran (2016) states that Debt on Equity Ratio does not affect the exposure of the US dollar exchange rate so there is no need to take hedging measures.

H3: Liquidity has an influence on hedging decisions

\section{Effect of leverage on hedging decisions.}

The leverage ratio shows how much a company uses debt to fund its activities. The leverage ratio can be measured using Debt Ratio. Debt Ratio is a ratio that describes the ratio of debt and assets in a company's funding and shows the ability of the company's assets to meet all its obligations. Exchange movements can affect the obligations that must be borne by the company. Companies that have high leverage ratios will tend to take hedging measures to minimize risk. Research conducted by Megawati, Wiagustini, Artini (2016) states that leverage has a positive but not significant relationship to hedging decisions. Meanwhile, according to Mata, Pangeran (2016) states that Debt on Equity Ratio does not affect the exposure of the US dollar exchange rate so there is no need to take hedging measures.

H4: Leverage has an influence on hedging decisions.

\section{RESEARCH METHODS}

This research is a quantitative descriptive study, where manufacturing company data is taken from the Indonesia Stock Exchange from 2015 to 2018. This research uses associative research that aims to determine the relationship of two or more variables (Sugiyono, 2009: 5). This calculation is done using Microsoft Excel 2019 and Eviews version 10. In this study, the hedging decision is the dependent variable. The implementation of hedging policies is measured using dummy variables. While the independent variables are firm size (FS), growth opportunity (GR), liquidity (LIQ), leverage (LEV).

\begin{tabular}{|l|l|l|l|}
\hline Variable Type & Symbol & Measurement. & Scale \\
\hline $\begin{array}{l}\text { Dependent } \\
\text { Hedging with derivatives }\end{array}$ & HEDG & $\begin{array}{l}\text { Companies that do not } \\
\text { conduct hedging activities } \\
=0 \\
\text { Companies conducting } \\
\text { hedging activities }=1 .\end{array}$ & Ratio \\
$\begin{array}{l}\text { Independent } \\
\text { Company size }\end{array}$ & FS & Gn total assets \\
Liquidity & LIQ & $\begin{array}{l}\text { Market Value of Equity } \\
\text { Book Value of Equity }\end{array}$ & Ratio \\
Leverage & LEV & $\frac{\text { Current Assets }- \text { Inventory }}{\text { Curabilities }}$ & Ratio \\
\hline
\end{tabular}

Table 1. Summary of Operational Definitions and Measurements.

Data collection techniques used in this study are archival data collection techniques, in the form of previous research, published reports and expert opinions sourced from books and secondary data on financial reports published during 2015 to 2018 by the Indonesia Stock Exchange through the www site .idx.co.id. 
The analytical method used in this study is logistic regression analysis. The reason for choosing this method is because the dependent variable in the research is a categorical variable, by giving a value of 0 for companies that do not do hedging activities, and 1 for companies that do hedging activities. The logistic regression equation model

in this study is described as follows:

$$
\begin{gathered}
\operatorname{Ln}\left(\frac{P i}{1-P i}\right)=\mathbf{Y}_{\text {it }} \\
\mathbf{Y}_{\text {it }}=\alpha_{\text {it }}+\beta_{1} \mathbf{X}_{\text {lit }}+\beta_{2} \mathbf{X}_{2 \text { it }}+\beta_{3} \mathbf{X}_{3 \mathrm{it}}+\beta_{4} \mathbf{X}_{4 i t}+\mathrm{e}_{\text {it }}
\end{gathered}
$$

Information:

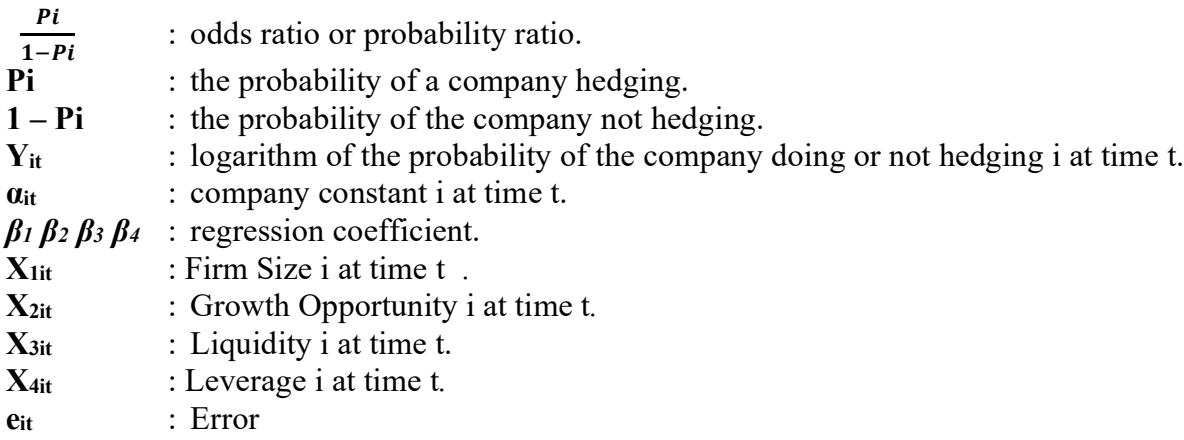

\section{RESULTS AND DISCUSSION.}

Manufacturing company is one of the business industries engaged in processing raw materials into finished goods which are then ready to be used or sold to consumers. Manufacturing business activities are also often referred to as production processes. Researchers obtained a sample of 40 companies in the period 2015-2018, so that the total sample used in this study was 160 samples.

Descriptive statistical analysis provides an overview of the maximum value, minimum value, average value and standard deviation of each variable, where the independent variables are Firm Size (X1), Growth Opportunity (X2), Liquidity (X3), Leverage (X4), while the dependent variable is the hedging decision making opportunity $(\mathrm{Y})$.

\begin{tabular}{lccccc}
\hline \hline & FS & GR & LIQ & LEV & HEDG \\
\hline \hline Mean & 29.05481 & 1.836813 & 1.098937 & 0.323063 & 0.262500 \\
Median & 28.95500 & 0.835000 & 0.865000 & 0.270000 & 0.000000 \\
Maximum & 32.47000 & 64.43000 & 4.750000 & 1.180000 & 1.000000 \\
Minimum & 26.67000 & -2.850000 & 0.010000 & 0.080000 & 0.000000 \\
Std. Dev. & 1.417855 & $\mathbf{5 . 4 5 6 9 3 7}$ & 0.921691 & 0.183926 & 0.441374 \\
Skewness & 0.427595 & 9.782800 & 1.715344 & 1.270219 & 1.079563 \\
Kurtosis & 2.413129 & 110.3157 & 5.829968 & 5.236148 & 2.165456 \\
Jarque-Berg. & 7.171778 & 79329.75 & 131.8556 & 76.36122 & 35.72192 \\
Probability & 0.027712 & 0.000000 & 0.000000 & 0.000000 & 0.000000 \\
Sum & 4648.770 & 293.8900 & 175.8300 & $\mathbf{5 1 . 6 9 0 0 0}$ & 42.00000 \\
Sum Sq. Dev. & 319.6396 & 4734.727 & 135.0727 & $\mathbf{5 . 3 7 8 7 9 9}$ & 30.97500 \\
Observations & 160 & 160 & 160 & 160 & 160 \\
\hline \hline
\end{tabular}

Table 2. Descriptive Statistics of Research Data.

The minimum Firm Size value shows a value of 26.67 and a maximum value of 32.47 , with an average value of 29.05 and a standard deviation value of 1.417855, which means that the distribution of Ln (total assets) is good. The highest value was found in PT Indah Kiat Pulp \& Paper Tbk in 2018 and the lowest value was in PT Asiaplast Industries Tbk in 2015.

The minimum value of Growth Opportunity shows a value of -2.85 and a maximum value of 64.43 , with an average value of 1.83 and a standard deviation value of 5.456937, which means that the distribution of Market Book Value is not good. The highest value was found at PT SLJ Global Tbk amounting to 64.43 in 2017 and the lowest value experienced by PT SLJ Global Tbk in 2016. 
The minimum value of Liquidity shows a value of 0.01 and a maximum value of 4.75 , with an average value of 1.09 and a standard deviation value of 0.921691 , which means good Current Ratio distribution. The highest value was found at PT Champion Pacific Indonesia Tbk by 4.75 in 2017. While the lowest value was experienced by PT Eterindo Wahanatama Tbk by 0.01 in 2018 .

The minimum Leverage value shows a value of 0.08 and a maximum value of 1.18 , with an average value of 0.32 and a standard deviation value of 0.183926, which means that the distribution of Debt Ratio is good. The highest value is at PT Central Proteina Prima Tbk at 1.18 in 2017 and the lowest value is at PT Indospring Tbk at 0.08 in 2017.

Logistic regression analysis is also called the logit model, which is a regression model used to analyze the dependent variable which is a data with a binary size or dichotomy or with a possibility between 0 and 1 .

\begin{tabular}{||c||c||c||c||c||}
\hline & FS & GR & LIQ & LEV \\
\hline \hline FS & 1.000000 & -0.068271 & -0.039212 & -0.170095 \\
GR & -0.068271 & 1.000000 & -0.041112 & -0.008961 \\
LIQ & -0.039212 & -0.041112 & 1.000000 & -0.603679 \\
LEV & -0.170095 & -0.008981 & -0.603679 & 1.000000 \\
\hline
\end{tabular}

Table 3. Multicollinearity Test Results.

Multicollinearity testing shows a correlation between Firm Size and Growth Opportunity of -0.066 , correlation between Firm Size and Liquidity of -0.0392 , Firm Size and Leverage of -0.170 , correlation between Growth Opportunity and Liquidity of -0.041 , correlation of Growth Opportunity and Leverage of -0.008 , the correlation of Liquidity and Leverage is -0.603 . According to Widardiono (2013: 104), if the correlation coefficient is above 0.85 , then multicollinearity is suspected in this model. So from the results of the output, this research does not have multicollinearity problems.

\begin{tabular}{lllr}
\hline \hline McFadden R-squared & $\mathbf{0 . 1 1 2 0 7 4}$ & Mean dependent var & 0.262500 \\
S.D. dependent var & 0.441374 & S.E. of regression & 0.417271 \\
Akaike info criterion & 1.084780 & Sum squared resid & 26.98783 \\
Schwarz criterion & 1.180879 & Log likelihood & -81.78237 \\
Hannan-Quinn griter. & 1.123802 & Deviance & 163.5647 \\
Restc deviance & 184.2098 & Restr. log likelihood & $-\mathbf{- 9 2 . 1 0 4 9 0}$ \\
LR statistic & 20.64507 & Avg. log likelihood & -0.511140 \\
Prob(LR statistic) & 0.000372 & & \\
\hline \hline
\end{tabular}

Table 4. McFadden R-Squared Test Results.

Testing Goodness of Fit with McFadden R-Squared produces a value of 0.112074 . This means that the independent variable in the model is able to explain the change in hedging probability by $11.20 \%$ and the rest $88.80 \%$ is explained by other variables outside the model. Goodness of Fit Testing with Hosmer and Lemeshow; s (HL) is used to test the null hypothesis that there is no difference between the model and data so that the model can be said to be fit. 


\begin{tabular}{|c|c|c|c|c|c|c|c|c|}
\hline \multicolumn{9}{|c|}{$\begin{array}{l}\text { Goodness-of-Fit Evaluation for Bingry Specification } \\
\text { Andrews and Hosmer-Lemeshow Tests } \\
\text { Equation: UNTITLED } \\
\text { Date: 02/08/20 Time: 01:17 } \\
\text { Grouping based upon predicted risk (randomize ties) }\end{array}$} \\
\hline & \multicolumn{2}{|c|}{ Quantile of Risk } & Actual & $\begin{array}{l}\text { Dep=0 } \\
\text { Expect }\end{array}$ & Actual & $\begin{array}{l}\text { Dep=1 } \\
\text { Expect }\end{array}$ & $\begin{array}{l}\text { Total } \\
\text { Qbs }\end{array}$ & $\begin{array}{l}\mathrm{H} \text {-L } \\
\text { Value }\end{array}$ \\
\hline $\begin{array}{l}1 \\
2 \\
3 \\
4 \\
5 \\
6 \\
7 \\
8 \\
9 \\
10\end{array}$ & $\begin{array}{l}0.0278 \\
0.0898 \\
0.1364 \\
0.1803 \\
0.1854 \\
0.2179 \\
0.2551 \\
0.3224 \\
0.3848 \\
0.5283\end{array}$ & $\begin{array}{l}0.0877 \\
0.1356 \\
0.1578 \\
0.1934 \\
0.2177 \\
0.2548 \\
0.3210 \\
0.3828 \\
0.5274 \\
0.6586\end{array}$ & $\begin{array}{l}18 \\
12 \\
14 \\
13 \\
13 \\
11 \\
13 \\
10 \\
11 \\
5\end{array}$ & $\begin{array}{l}15.0310 \\
14.1683 \\
13.8687 \\
13.1689 \\
12.7068 \\
12.1925 \\
11.5201 \\
10.1748 \\
9.07633 \\
6.29485\end{array}$ & $\begin{array}{l}0 \\
4 \\
2 \\
3 \\
3 \\
5 \\
3 \\
6 \\
5 \\
11\end{array}$ & $\begin{array}{l}0.86904 \\
1.83170 \\
2.33326 \\
2.83115 \\
3.29341 \\
3.80748 \\
4.47989 \\
5.82525 \\
6.92367 \\
9.70515\end{array}$ & $\begin{array}{l}18 \\
18 \\
18 \\
18 \\
18 \\
18 \\
18 \\
18 \\
18 \\
18\end{array}$ & $\begin{array}{l}1.03152 \\
2.89858 \\
0.05573 \\
0.01224 \\
0.03291 \\
0.49014 \\
0.67898 \\
0.00824 \\
0.94218 \\
0.43911\end{array}$ \\
\hline 10 & & Total & 118 & 118.000 & 42 & 42.0000 & 180 & 6.58962 \\
\hline $\begin{array}{l}\mathrm{H}-\mathrm{L} \\
\mathrm{An}\end{array}$ & $\begin{array}{l}\text { Statistio } \\
\text { rews Stg }\end{array}$ & & $\begin{array}{l}6.5896 \\
19.4673\end{array}$ & & $\begin{array}{l}\text { Prob. } \\
\text { Prob. }\end{array}$ & $\begin{array}{l}\mathrm{i}-\mathrm{Sa}(8) \\
-S o(10)\end{array}$ & $\begin{array}{l}0.5815 \\
0.0347\end{array}$ & \\
\hline
\end{tabular}

Table 5. Hosmer and Lemeshow Test Results

The output display shows that the value of HL statistics is 6.5896 with a significance probability of 0.5815 , where the probability value is above 0.05 . If the value of Statistics HL Goodness of Fit is greater than 0.05 , then the null hypothesis cannot be rejected and means that the model is able to predict the value of its observations or it can be said that the model is acceptable because it matches the observations. dependent variable because it matches the observation.

Likelihood Ratio Test to test whether all explanatory variables jointly influence the dependent variable. If chisquare count $>$ chi-square table value, then $\mathrm{H} 0$ is rejected

\begin{tabular}{lllr}
\hline \hline McFadden R-squared & 0.112074 & Mean dependent var & 0.262500 \\
S.D. dependent var & 0.441374 & S.E. of regression & 0.417271 \\
Aksike info criterion & 1.084780 & Sum squared resid & 26.98783 \\
Schwarz criterion & 1.180879 & Log likelihood & -81.78237 \\
Hannan-Quinn griter. & 1.123802 & Deviance & 163.5647 \\
Restr deviance & 184.2098 & Restr log likelihood & -92.10490 \\
LR statistic & $\mathbf{2 0 . 6 4 5 0 7}$ & Avg. log likelihood & -0.511140 \\
Prob(LR statistic) & $\mathbf{0 . 0 0 0 3 7 2}$ & & \\
\hline \hline
\end{tabular}

Table 6. Likelihood Ratio Test Results.

Based on the estimation results, the statistical LR or chi-square calculated is 20.64507 , while the chisquare value of the table df $159, \alpha=0.05$ is 189.4242 . Statistical LR or chis-square value $(20.64507)<$ chi-square table value (189.4242), then the decision is to accept H0, which means that all explanatory variables together do not affect the dependent variable.

$\mathrm{Z}$ statistical tests are performed to determine whether the independent variables individually affect the dependent variable. If the probability value $<\alpha$, then $\mathrm{H} 0$ is rejected, which means that the independent variable affects the dependent variable, whereas if the probability value $>\alpha$, then $\mathrm{H} 0$ is accepted.

\begin{tabular}{crrrr}
\hline \hline Variable & Coefficient & Std. Error & z-Statistic & Prob. \\
\hline \hline C & -18.57202 & 4.582931 & -4.052432 & 0.0001 \\
FS & 0.597006 & 0.148904 & 4.009332 & 0.0001 \\
GR & 0.002105 & 0.038889 & 0.054132 & 0.9568 \\
LIQ & -0.250686 & 0.303674 & -0.825512 & 0.4091 \\
LEV & 0.913400 & 1.314964 & 0.694620 & 0.4873 \\
\hline \hline
\end{tabular}

Table 7. Z Test Results. 
$Z$ Test Results of each independent variable on the dependent variable:

\section{Firm Size Variable}

Based on table 8 , it can be seen that the probability value of the independent variable Firm Size is 0.0001 . When compared with $\alpha=0.05$, the probability value $(0.0001)<\alpha$ value. So it can be taken a decision that the Firm Size variable influences hedging decision making.

\section{Growth Opportunity Variable}

Based on table 8, it can be seen that the probability value of the independent variable Growth Opportunity is 0.9568 . When compared with $\alpha=0.05$, the probability value $(0.9568)>\alpha$ value. Then it can be concluded that the Growth Opportunity variable does not affect hedging decision making.

\section{Liquidity Variable}

Based on table 8 , it can be seen that the probability value of the independent variable Liquidity is 0.4091 . When compared with $\alpha=0.05$, the probability value $(0.4091)>\alpha$ value. So it can be concluded that the Liquidity variable does not affect hedging decision making.

Leverage Variable

Based on table 8 , it can be seen that the probability value of the independent variable leverage is 0.4873 . When compared with $\alpha=0.05$, the probability value $(0.4873)>\alpha$ value. Then it can be concluded that the Leverage variable has no effect on hedging decision making.

The logit model estimation results, the output can be seen below:

\begin{tabular}{|c|c|c|c|c|}
\hline \multicolumn{5}{|c|}{$\begin{array}{l}\text { Dependent Variable: HEDG } \\
\text { Method: ML - Binary Lqgitw(Newton-Raphson / Marquardt steps) } \\
\text { Date: 02/08/20 Time: 01:01 } \\
\text { Sample: } 20152018 \\
\text { Included observations: } 180 \\
\text { Convergence achieved after } 4 \text { iterations } \\
\text { Coefficient covariance computed using observed Hessian }\end{array}$} \\
\hline Variable & Coefficient & Std. Error & z-Statistic & Prob. \\
\hline $\begin{array}{l}\text { C } \\
\text { FS } \\
\text { GR } \\
\text { LIQ } \\
\text { LEV }\end{array}$ & $\begin{array}{r}-18.57202 \\
0.597006 \\
0.002105 \\
-0.250686 \\
0.913400\end{array}$ & $\begin{array}{l}4.582931 \\
0.148904 \\
0.038889 \\
0.303674 \\
1.314964\end{array}$ & $\begin{array}{r}-4.052432 \\
4.009332 \\
0.054132 \\
-0.825512 \\
0.694620\end{array}$ & $\begin{array}{l}0.0001 \\
0.0001 \\
0.9568 \\
0.4091 \\
0.4873\end{array}$ \\
\hline $\begin{array}{l}\text { McFadden R-squared } \\
\text { S.D. dependent var } \\
\text { Aksike info criterion } \\
\text { Schwarz criterion } \\
\text { Hannan-Quinn criter. } \\
\text { Restc deviance } \\
\text { LR statistic } \\
\text { Rrob(LR statistic) }\end{array}$ & $\begin{array}{l}0.112074 \\
0.441374 \\
1.084780 \\
1.180879 \\
1.123802 \\
184.2098 \\
20.64507 \\
0.000372\end{array}$ & \multicolumn{2}{|c|}{$\begin{array}{l}\text { Mean dependent var } \\
\text { S.E. of regression } \\
\text { Sum squared resid } \\
\text { Log likelihood } \\
\text { Deviance } \\
\text { Restr. log likelihood } \\
\text { Avg. log likelihood }\end{array}$} & $\begin{array}{r}0.262500 \\
0.417271 \\
26.98783 \\
-81.78237 \\
163.5647 \\
-92.10490 \\
-0.511140\end{array}$ \\
\hline $\begin{array}{l}\text { Qbs with Dep }=0 \\
\text { Qbs with Dep }=1\end{array}$ & $\begin{array}{r}118 \\
42\end{array}$ & \multicolumn{2}{|l|}{ Total,$a b s$} & 160 \\
\hline
\end{tabular}

Table 8. Logit Model Estimation Results.

Based on the results of the above output, the logistic regression model equation is obtained as follows:

$$
\begin{aligned}
\operatorname{Ln}\left(\frac{P i}{1-P i}\right)= & -18.57202+0.597006 F S+0.002105 G R-0.250686 L I Q \\
& +0.913400 L E V
\end{aligned}
$$

The first hypothesis states that firm size has an influence on hedging decision making. Based on the $\mathrm{Z}$ test it is known that the firm size variable has a coefficient in the positive direction of 0.597006 . The resulting probability value of 0.0001 with a level of confidence $\alpha=5 \%$. The probability value is smaller than $\alpha=5 \%$, then $\mathrm{H} 1$ is accepted. These conditions indicate that firm size influences hedging decision making in manufacturing 
companies. Large companies certainly have large operational activities and are more risky because there are many trade transactions that occur, especially international trade. One of the factors that pose a risk is the changing global economic situation, which causes uncertainty about the exchange rate. International trade that occurs in large companies, raises the risk of fluctuations in foreign exchange rates. Therefore, the company makes the decision to hedge to mitigate the risk.

Research conducted by Ahmad, Mardiyati, and Nashrin (2015), and Ozek (2016), also stated that companies that have large firm sizes, have a tendency to hedge. Large companies have extensive operational activities and can be more risky. Then the company wants to mitigate the risk of fluctuations in currency exchange rates. While research conducted by Krisdian and Badjra (2017) states that firm size has no effect on hedging decision making.

The second hypothesis states that growth opportunity has an influence on hedging decision making. Based on the $\mathrm{Z}$ test it is known that the growth opportunity variable has a coefficient in the positive direction of 0.002105 . The probability value obtained is 0.9568 with a confidence level $\alpha=5 \%$. The probability value is greater than $\alpha=$ $5 \%$, then $\mathrm{H} 2$ is rejected. These conditions indicate that growth opportunity has no effect on hedging decisions in manufacturing companies.

Research conducted by Herianti and Juwita (2018), Widyagoca and Lestari (2016), also states that high growth rates within a company, do not influence the decision to hedge. While research conducted by Kussulistyanti, Mahfudz (2016).

The third hypothesis states that liquidity has an influence on hedging decision making. Based on the $\mathrm{Z}$ test it is known that the liquidity variable has a coefficient value in the negative direction of -0.250686 . The resulting probability value of 0.4091 with a level of confidence $\alpha=5 \%$. The probability value is greater than $\alpha=$ $5 \%$, then $\mathrm{H} 3$ is rejected. These conditions indicate that liquidity has no effect on hedging decision making in manufacturing companies.

Research conducted by Ahmad, Mardiyati and Nashrin (2015), Megawati, Wiagustini and Artini (2016), also stated that the level of liquidity of a company does not affect the decision to hedge. While research conducted by Sofia, Yuneline (2019), states that liquidity influences hedging decisions.

The fourth hypothesis states that leverage has an influence on hedging decision making. Based on the $\mathrm{Z}$ test it is known that the leverage variable has a coefficient in the positive direction of 0.913400 . The probability value obtained is 0.4873 with a level of confidence $\alpha=5 \%$. The probability value obtained is greater than than $\alpha$ $=5 \%$, then $\mathrm{H} 4$ is rejected. These conditions indicate that leverage does not affect hedging decision making in manufacturing companies.

Research conducted by Utami, Sriyanto and Purbasari (2018), also states that the higher the level of a company's debt, it has no effect in hedging. While research conducted by Ozek (2016), Tanha, Dempsey, Labeb (2017), Wijaya, Astuti, and Nugraha (2018), states that leverage has an influence on hedging decision making.

\section{CONCULUSION AND SUGGESTIONS}

Based on research that has been done, it can be concluded that:

Firm Size indicator which is proxied by Ln (Total Assets), has an influence on hedging decision making, Growth Opportunity indicator which is proxied by Market to Book Value, has no influence on hedging decision making, Liquidity indicator which is proxied by Current Ratio, has no effect on hedging decision making, and the Leverage indicator proxied by Debt Ratio, has no influence on hedging decision making.

Based on the research results obtained, it is recommended for companies that have a large size so that they can do hedging to protect assets owned by the company from losses arising from foreign currency fluctuations.

\section{REFERENCE.}

Ahmad, G., Mardiyati, U., \& Nashrin, A. (2015). Analysis Of Hedging Determinants With Foreign Currency Derivative Instruments Listed On BEI Period 2012-2015. Indonesian Science Management Research Journal, 6.

Alika, R. (2019, May 6). Regarding Rupiah Weakening, BI: The Impact of the US-China Trade War. (S. Tobing, Ed.) Retrieved from https://katadata.co.id/berita/2019/05/06/soal-pelambat-rupiah-bi-imbasperangdagang-as-tion Chinese.

Bae, S., Kim, H., \& Kwon, T. (2018). Currency Derivatives for Hedging: New Evidence on Determinants, Firm Risk, and Performance. Wiley Periodicals, Inc., pp. 446-467. DOI: 10.1002 / fut.21894.

Fahmi Irham, S. M. (2010). Risk Management Theories, Cases and Solutions. Bandung: Alfabeta.

Faculty of Economics and Business, Diponegoro University, Semarang. (2017). Multivariate and Econometric Analysis. Semarang: Diponegoro University Publisher Agency.

Gujarati, D. d. (2012). Basics of Econometrics Issue 5. Jakarta: Four Salemba.

Hady, H. (2010). International Financial Management Edition 2. Jakarta: Publisher Media Partner Discourse.

Harjito, A., \& Martono. (2014). Financial Management Second Edition Fourth Edition. Yogyakarta: Ekonisia Publisher. 
Herianti, S., \& Juwita, R. (2017). The Effect of Liquidity, Financial Distress, Growth Opportunity and Institutional Ownership on Hedging Decisions in the Manufacturing Sector Listed on the Indonesia Stock Exchange for the Period of 2015-2017.

Krisdian, N., \& Badjra, I. (2017). The Effect of Company Size, Debt Levels, and Financial Difficulties on Hedging Decisions in Indonesian Manufacturing Companies. E-Journal of Management of Udayana University, 6 (3), 1452-1477. ISSN: 2302-8912.

Kussulistyanti, M., \& Mahfudz. (2016). Analysis of Factors Affecting Hedging Decisions with Foreign Currency Derivatives (Study of Non-Financial Companies Listed on the Indonesia Stock Exchange for the Period of 2011-2014). Diponegoro Journal of Management, 4 (3), 1-14. ISSN: 2337-3806

Kusuma, Risky (2015). "The Effect of Ownership Structure, Profitability, and Efficiency on Risks in Indonesian Banking for the 2010-2013 Period

The Company's Financial and Annual Reports go public. (2019). Retrieved from https://www.idx.co.id/companynoted/report-finance-and-year/.

Indonesia Economic Report 2018. (2019, March 27). Retrieved from www.bi.go.id.

Lenee, T., \& Oki, J. (2017). Financial Derivatives and Firm Performance: Empirical Evidence from Financial and Non-financial Firms. British Journal of Economics, Management \& Trade, 1-36. DOI: 10.9734 / BJEMT / $2017 / 30106$

Li, H., Visaltanachoti, N., \& Luo, R. (2014). Foreign Currency Derivatives and Firm Value: Evidence from New Zealand. Journal of Financial Risk Management, 3, 96-112. DOI: 10.4236 / jfrm.2014.33010

M., R. R. (2008). International Economy.

Mata, V., \& Prince, P. (2016). Dollar Exchange Rate Exposures (US \$) in Multinational Companies in Indonesia. Journal of Business Management, 11, No. 2, 79-94.

Maulana, D. (2018, October 16). Indonesia's Development in International Trade. Retrievedfrom.https:/www.kompasiana.com/dicky99014/5bc54be8677ffb3f4a68c643/perkembanganindonesia-in-trading-international?page $=2$.

Megawati, I., Wiagustini, L., \& Artini, L. (2016). Determination of Hedging Decisions in Manufacturing Companies on the Indonesia Stock Exchange. E-Journal of Economics and Business, Udayana University 5 (10), 3391-3418. ISSN: 2337-3067

Mayfi, Fathimah Fatihatul Fithri. (2014) "Analysis of the Effects of Micro and Macroeconomic Factors on Stock Returns in the Jakarta Islamic Index (JII)".

Nisaputra, R. (2018, September 18). BI: US-China Trade War Still Triggers Rupiah to Weaken Again.

Ozek, P. (2016). An Empirical Investigation On The Use Of Derivative Instruments Industrial Firms In Turkey. Finansial Arastirmalar ve Calismalar Dergisi, 173-187. DOI:10.14784/JFRS.23358

Pallavi, E. (2015). A New Era of Currency Derivatives Market in India. IOSR Journal of Economics and Finance, 6(3), 36-40. e-ISSN : 2321-5923

Putera, A. (2018, September 19). This Explains Why the United States Can Affect the Rupiah. (E. Djumena, Ed.) Retrieved from https://ekonomi.kompas.com/read/2018/09/19/151600126/ini-explain- why-americaunion-bisa- affect- the body.

Ratmoko, I. G. (2017). Multivariate and Economical Analysis: Theory, Concepts and Applications with Eviews 10. Diponegoro University Publisher Agency.

Santoso, T. (2018, March 22). Overshooting Phenomenon. Retrieved from https://news.detik.com/column/d3930737/fenomena-overshooting-rupiah.

Setiobudi, E. (n.d.). Urgency of Rupiah Exchange Rate Mitigation. Retrieved from https://news.detik.com/kolom/d-4111011/urgensi-mitigasi-nilai-tukar-rupiah.

Sofia, R., \& Yuneline, M. (2019, March). Determination of Hedging Decision Making in Foreign Currency Derivative Hedging Decision Instruments. ISEI Business and Management Review, III, No. 1, 16-25. doi: e-ISSN: 2614-6290

Sri Mulyani: 2020 State Budget Is Designed to Anticipate Uncertainty. (2019, August 21). Retrieved from Tempo.co.

Sudana, I. (2015). Corporate Financial Management Theory and Practice Edition 2. Erlangga Publisher.

Tanha, H., Dempsey, M., \& Labeb, M. (2017, 10 20). Derivatives Usage by Australian Industrial Firms: Pre-, during and post-GFC. Review of Economics \& Finance.

Utami, H., Sriyanto, \& Purbasari, I. (2018, April). Determination of Hedging Decisions with Financial Derivative Instruments in Manufacturing Companies on the Indonesia Stock Exchange 2011-2016. 13.

Widyagoca, I., \& Lestari, P. (2016). The Effect of Leverage, Growth Opportunities, and Liquidity on Hedging Decision Making of PT. Indosat TBK. E-Journal of Management of Udayana University, 5, 1282-2308. ISSN: 2302-8912 
Wijaya, L., Astuti, P., \& Nugraha, D. (2018, December). Analysis of Factors Affecting Derivative Instruments as Hedging Decision Making. 4 No. 02. ISSN: 2502-3497

Winarno, W. W. (2011). Analysis of Econometrics and Statistics with Eviews. Yogyakarta: STIM YKPN. 